Berkala Ilmu Perpustakaan dan Informasi, Vol. 13, No. 1, Juni 2017, Hal. 191-204 DOI: http:// 10.22146/bip.23136

ISSN 1693-7740 (Print), ISSN 2477-0361 (Online)

Tersedia online di https://jurnal.ugm.ac.id/bip

\title{
DESA TANI, PENDUDUK MISKIN, LUMBUNG PADI, DAN LAYANAN IMPLEMENTATIF PERPUSTAKAAN DESA DI KECAMATAN PAMARICAN KABUPATEN CIAMIS
}

\author{
Pawit M. Yusup $^{1}$, Engkus Kuswarno ${ }^{2}$, Nuning Kurniasih ${ }^{3}$, Ute Lies Siti Chodijah ${ }^{1}$ \\ ${ }^{1}$ Program Studi Ilmu Perpustakaan, Fikom, Universitas Padjadjaran \\ ${ }^{2}$ Pusat Studi Komunikasi Lingkungan, Fikom, Universitas Padjadjaran \\ ${ }^{3}$ Laboratorium CMC, Fikom, Universitas Padjadjaran \\ e-mail: pawitmy@gmail.com
}

Naskah diterima: 20 Maret 2017, direvisi: 12 September 2017, disetujui: 19 Oktober 2017

\begin{abstract}
ABSTRAK
Penelitian pendahuluan ini bertujuan untuk menggali data awal mengenai rintisan pembangunan sistem usaha bersama kelompok tani berupa lumbung padi (lumbung paceklik) di desa. Jenis kelompok usaha ini berbasis pada sistem pengetahuan lokal yang berkarakter kebersamaan, kesetiakawanan, gotong royong, dan terbukti tangguh dalam menghadapi perubahan global. Untuk memulainya diperlukan langkah-langkah teknis-strategis dan terpadu, yang melibatkan berbagai unsur terkait, seperti perguruan tinggi, badan usaha yang ada di desa, pemuka masyarakat, kelompok usaha masyarakat, perpustakaan desa, dan unsur lainnya. Pendekatan yang digunakan adalah observasi lapangan dan wawancara dengan sejumlah unsur terkait. Adapun langkah teknis yang dilakukannya adalah sebagai berikut: (a) menggali informasi awal melalui diskusi dengan masyarakat mengenai peta permasalahan kemiskinan pedesaan dilihat dari aspek penyediaan sarana pelatihan usaha berbasis membaca sumber-sumber informasi kewirausahaan; (b) belajar bersama masyarakat miskin pedesaan mengenai potensi usaha di desa atas dasar pandangan dan pengalaman mereka; (c) menyusun model usaha berbasis pemanfaatan sumber bacaan yang cocok dengan jenis usaha di desa; (d) diskusi mengenai rintisan penyelenggaraan kelompok usaha berbasis Lumbung Padi di desa, yang terbukti tahan terhadap perubahan global; dan (e) mensinergikan semua kegiatan yang dilakukan oleh masing-masing unsur di atas, dalam bentuk model harmoni desa tani, penduduk miskin, lumbung padi, dan perpustakaan desa.
\end{abstract}

Kata kunci: Desa Tani; Penduduk Miskin; Lumbung Padi; Perpustakaan Desa.

\begin{abstract}
This preliminary study aims to explore the initial data on the pilot system of the development of joint venture within farmer groups of granary (granaries famine). The farmer groups work based on local knowledge with their commitment of togetherness, solidarity, mutual help, and proved resilient to face global change. To start the activities, several aspects are needed to support such as necessary technical-strategic and integrated approach, involving various related elements, such as universities, business entities that exist in the village, community leaders, business groups community and village library. The approach used is field observation and interviews.. The technical steps for the process were as follows: (a) exploring the initial information through discussions with the community about the problems of rural poverty maps from the aspects of the provision of business training based reading information sources entrepreneurship; (b) communicating with poor rural communities about the potential for business in the village based on their views and experiences; (c) developing a business model based on the use of business reading materials; (d) conducting a discussion on the pilot implementation of a business group based Lumbung Padi villagetowards global change; and (e) synergizing all activities performed by each of the above elements, in the form of a model village harmony peasants, the poor, granary, and the village library.
\end{abstract}

Keywords: Farming Village; Poor; Granary; Village Library 


\section{A. PENDAhuluan}

Kajian mengenai orang miskin atau penduduk miskin dari sudut pandang mana pun tetap memiliki nilai strategis dalam proses pembangunan manusia Indonesia secara keseluruhan, setidaknya bagi kalangan ilmuwan, peneliti, dan para pengambil kebijakan. Hasil kajiannya pun memiliki manfaat yang jelas dalam konstelasi pembangunan di semua lini, mulai dari lini yang paling atas yakni kelompok masyarakat elit dan mapan secara ekonomi, sampai pada lini yang paling bawah, yakni kelompok masyarakat yang secara sosial ekonomi berada pada posisi "tidak memiliki apa-apa” (Yusup, Pawit M., 2013). Dalam beberapa kepustakaan digital, kelompok masyarakat pada posisi ini dikenal dengan nama orang pinggiran (Lihat Program Siaran Televisi Trans7 (2012-2017). Tulisan ini lebih banyak menggunakan istilah orang miskin, penduduk miskin, warga miskin, keluarga miskin, atau massyarakat miskin, untuk merujuk kepada mereka yang dalam kehidupan sosialnya berada dalam posisi "pinggiran". Mereka termasuk orang-orang yang terpinggirkan dalam pembangunan.

Dalam kehidupan sosialnya, penduduk miskin hidup berbaur dengan penduduk lainnya yang secara sosioeonomi tidak termasuk kategori miskin. Yang membedakannya hanyalah pada aspek-aspek kepemilikan harta benda atau properti lain yang secara fisik dan sosial menggambarkan kedudukan pada stratifikasi yang berbeda. Dilihat dari segi batasan saja, misalnya, konsep miskin itu bervariasi, terutama jika dilihat dari sudut pandang etik dan emik. Miskin bisa jadi bermakna tidak memiliki apa-apa dalam hampir segalanya. Miskin juga bisa dimaknai sebagai orang yang ditakdirkan belum berhasil dalam berusaha mencari penghidupan. Miskin juga bisa diartikan sebagai orang yang sudah berusaha sekuat tenaga dalam bekerja mencari rizki namun gagal; artinya mereka sudah bekerja, berjuang dan berusaha secara sungguhsungguh, namun belum berhasil. Tegasnya, konsepsi miskin dan kemiskinan bersifat kontekstual(Yusup, Pawit M., 2014).
Penduduk miskin hidup tersebar di hampir semua wilayah, baik di kota maupun di desa, bahkan menurut laporan Bank Dunia, sebagian besar penduduk berkategori miskin itu tinggal di pedesaan dengan kondisi yang memprihatinkan. Data dari Bank Dunia (2010) melaporkan bahwa sebagian besar penduduk miskin tinggal di pedesaan $(69 \%)$, bekerja di sektor pertanian (64\%), sifat pekerjaan adalah informal (75\%), dan sekitar $22 \%$ adalah sebagai pekerja keluarga yang tidak dibayar. Sementara itu, pada dimensi non-ekonomi, konsep kemiskinan terkait dengan kapasitas sumberdaya manusia, aksesibilitas terhadap kebutuhan utama, dan keterlibatan pada kesempatan kerja dan berusaha dalam arti luas, termasuk keterbatasan dalam mengakses dan menemukan informasi mengenai apapun yang bisa dijadikan "pintu" menuju kegiatan usaha untuk memberdayakan diri dan keluarga.

Gambaran realitas kemiskinan di atas, utamanya untuk menegaskan bahwa terdapat banyak sekali penduduk miskin yang tersebar di hampir semua wilayah, termasuk di pedesaan. Penelitian ini mengambil lokasi di Jawa Barat bagian Selatan, terutama di pedesaan yang tersebar di beberapa kabupaten seperti, Pangandaran, Ciamis, Tasikmalaya, Garut, Cianjur, dan Sukabumi. Sebagian besar penduduk miskin di wilayah ini bekerja sebagai buruh serabutan di sektor pertanian tradisional. Selain itu, dipilih lokasi ini dengan pertimbangan bahwa menurut informasi yang dikemukakan oleh BPS (Badan Pusat Statistik), kesenjangan antara penduduk kaya dan miskin di Jawa Barat termasuk tertinggi di Indonesia (Suara.com, 20 April 2016). Dengan melihat kondisi ini, maka tepat sekali tema penelitian ini dengan program NAWACITA-nya Presiden Joko Widodo dan Wakil Presiden Jusup Kalla, khususnya pada butir ke-3, yakni "Membangun Indonesia dari pinggiran dengan memperkuat daerah-daerah dan desa dalam kerangka negara kesatuan". (Sumber: Kompas.com, diakses tanggal 20 April 2016).

Sementara itu, dilihat dari aspek sarana dan prasarana yang mendukung terciptanya suasana berwirausaha di kalangan penduduk miskin di 
wilayah ini, masih tergolong belum merata. Dilihat dari sektor pendidikan dan fasilitas belajar untuk meningkatkan keterampilan berusaha seperti adanya perpustakaan umum dan perpustakaan desa, pusat-pusat pelatihan usaha, masih belum bisa menjangkau penduduk yang berkategori miskin. Fasilitas, sarana, dan prasarana yang ada lebih banyak menguntungkan penduduk bukan kelompok miskin. Penduduk berkategori miskin tetap seperti kondisinya sekarang, tidak tersentuh oleh program-program pembangunan yang digulirkan pemerintah/negara (Yusup, Pawit M., 2014).

Berangkat dari kondisi sosial, ekonomi, budaya, pendidikan, dan suasana kedesaan seperti digambarkan di atas, dan setelah dilakukan prasurvei dan kajian yang sudah dilakukan dalam beberapa tahun terakhir, peneliti berinisiasi untuk menggali kembali data awal dan mengkaji secara lebih nyata. Kajian detilnya adalah pada sistem pengetahuan lokal sebagai jatidiri kehidupan desa di Jawa Barat Bagian Selatan. Wilayah ini secara umum memiliki sifat kesetiakawanan, gotong royong, tangguh dalam menghadapi perubahan global. Terkait dengan hal ini, maka diperlukan langkah-langkah strategis dan teknis secara terpadu dari para pelaku pembangunan di tempat ini. Semua unsur terkait, perlu bersinergi dan proaktif dalam melaksanakan langkahlangkah dimaksud. Banyak unsur yang terlibat secara aktif dalam kegiatan ini. Sebagai contoh, perguruan tinggi mengimplementasikan program-program tridarmanya. Badan-badan usaha yang ada di desa melakukan kegiatan usaha berbasis kebersamaan. Para pemuka masyarakat melakukan gerakan sosial dan proaktif dalam membimbing anggota masyarakat. Kelompok-kelompok masyarakat yang peduli terhadap kehidupan desa bisa bergerak melalui berbagai kegiatan kreatifnya. Perpustakaan desa bisa melakukan programprogram layanan implementatif berbasis pendampingan. Selain itu, unsur-unsur lain di masyarakat yang peduli dengan upaya membangun kembali jatidiri desa, bisa bergerak melalui berbagai kegiatan kedesaannya.
Tujuan dalam penelitian ini dapat disusunnya kembali sistem pengetahuan lokal (local knowledge) sebagai jatidiri desa yang mandiri dan tangguh menghadapi perubahan global. Salah satu cara yang diperlukan saat ini adalah: dibangunnya kembali sistem usaha Lumbung Desa sebagai penyangga cadangan pangan penduduk desa di saat paceklik; dibangunnya komunitas usaha berbasis membaca buku dan media TTG di kalangan penduduk miskin pedesaan; dan terselenggarakannya Perpustakaan desa berkonten pengetahuan lokal yang berfungsi sebagai penyedia dan sekaligus sebagai fasilitator pendampingan membaca untuk usaha di desa.

Sementara itu, setidaknya ada dua manfaat khusus yang diperoleh dalam penelitian ini. Yang pertama keterlibatan peran perguruan tinggi terhadap perubahan karakter sosioekonomi dan sosioteknologi informasi dan komunikasi di pedesaan tampak pada berbagai bentuk kegiatan yang berbasis pada tridarmanya, yakni melalui kegiatan penelitian dan pengabdian kepada masyarakat. Harmoni lumbung desa dan perpustakaan desa untuk penduduk miskin di desa adalah wujud nyata dari kehidupan sosial ekonomi pedesaan. Manfaat berikutnya adalah, melalui kehadiran lumbung desa, penduduk miskin di desa akan memiliki cadangan makanan yang cukup di saat paceklik. Sementara itu, kehadiran Perpustakaan Desa dan layanannya yang implementatif, bisa menjadi perekat hubungan yang harmonis di kalangan mereka. Dalam jangka panjang, kondisi seperti ini bisa menghidupkan kembali suasana kehidupan pedesaan yang berkarakter gotong royong dan rasa kesetiakawanan sosial.

Penelitian ini memiliki urgensi (keutamaan) dalam pembangunan lokal atau wilayah terbatas, namun hasilnya diharapkan bisa berimplikasi terhadap kemanfaatan yang lebih luas atau nasional. Artinya, di masa yang akan datang, hasil penelitian ini bisa diaplikasikan pada wilayah-wilayah lain yang berkarakter mirip, yakni kondisi penduduk miskin pedesaan yang umumnya bekerja sebagai petani 
tradisional dan bahkan sebagian besar sebagai buruh serabutan di sektor pertanian tradisional.

\section{B. TINJAUAN PUSTAKA}

Permasalahan kemiskinan pedesaan sampai saat ini masih menarik untuk dikaji, sebab hal ini melekat dengan realitas kehidupan dan penghidupan umat manusia sepanjang zaman. Dahulu, sekarang, dan di masa yang akan datang, orang-orang miskin tetap ada di manapun di bumi ini. Sebagai contoh, orang miskin tetap ada pada setiap komunitas penduduk di suatu wilayah dan negara. Keberadaan mereka berbaur dengan penduduk non miskin dalam lingkup wilayah dimaksud. Di Indonesia, jumlah orang miskin masih tergolong cukup banyak, yakni mencapai sekitar 11 persen atau sekitar 27,73 juta jiwa (Sumber: BPS, 2015). Sebagian besar mereka tinggal di pedesaan $(69 \%)$, bekerja di sektor pertanian (64\%), sifat pekerjaan adalah informal (75\%), dan sekitar $22 \%$ adalah sebagai pekerja keluarga yang tidak dibayar (Sumber: Bank Dunia, 2016).

Batasan miskin cukup beragam. Maknanya cenderung relatif dan kontekstual terutama jika dilihat dari sudut pandang emik. Di sisi lain bisa jadi cenderung "menuduh" jika sudut pandangnya adalah etik-objektif. Philips dan Legates (1981), dalam Badruddin, Syamsiah, (2009), mengemukakan empat pandangan tentang miskin, yakni: (1) Miskin dipandang sebagai akibat dari kegagalan personal dan sikap tertentu khususnya ciri-ciri sosial psikologis individu dari si miskin yang cenderung menghambat untuk melakukan perbaikan nasibnya. Orang miskin tidak melakukan rencana ke depan, menabung dan mengejar tingkat pendidikan yang lebih tinggi. (2) Miskin dilihat sebagai akibat dari subkultur tertentu yang diturunkan dari generasi ke generasi. Orang miskin adalah kelompok masyarakat yang memiliki subkultur tertentu yang berbeda dari golongan yang tidak miskin, seperti memiliki sikap fatalis, tidak mampu melakukan pengendalian diri, berorientasi pada masa sekarang, tidak mampu menunda kenikmatan atau melakukan rencana bagi masa mendatang, kurang memiliki kesadaran kelas, atau gagal dalam melihat faktor-faktor ekonomi seperti kesempatan yang dapat mengubah nasibnya. (3) Miskin dilihat sebagai akibat kurangnya kesempatan, kaum miskin selalu kekurangan dalam bidang keterampilan dan pendidikan untuk memperoleh pekerjaan di masyarakat. (4) Miskin dianggap sebagai suatu ciri struktural dari kapitalisme. Dalam masyarakat kapitalis, sebagian orang menjadi miskin karena yang lain menjadi kaya.

Sudah banyak kepustakaan terdahulu yang mengkaji tentang kemiskinan pedesaan dan aspek-aspeknya, baik dengan menggunakan pendekatan etik-kuantitatif, emik-kualitatif, atau keduanya. Dari sisi pandang emik, misalnya, makna miskin sangat bervariasi, karena mengandung konteks secara langsung sesuai dengan sudut pandang, pengetahuan, perasaan, dan pengalaman orang-orang miskin sendiri. Dalam konteks ini, miskin bukan hanya masalah kepemilikan harta benda. Ada orang miskin yang hidupnya "mentereng", namun ada orang orang yang sebenarnya memiliki banyak harta benda namun hidupnya sangat bersahaja sehingga tampak seperti orang miskin.

Sementara itu, dilihat dari sisi bidang kajian, para peneliti dan ilmuwan juga banyak mengkaji secara lebih serius, baik dari sisi pandang ekonomi maupun dari sisi pandang non ekonomi. Beberapa di antaranya adalah sebagai berikut: (1) Hasil penelitian Yusup, Pawit M.; Rahmawati, Tine Silvana; Subekti, Priyo (2013:21-28), yang meneliti tentang peta lingkup informasi penghidupan orang miskin pedesaan; (2) Hasil penelitian Yusup, Pawit M. (2013), dengan tema memetakan jenis kebutuhan utama orang miskin pedesaan dan variasi jenis informasi penghidupan yang dicari; (3) Hasil penelitian Yusup, Pawit M. dan Neneng Komariah (2013), dengan judul Dimensi Pencarian Dan Penggunaan Informasi Kesehatan Pada Keluarga Prasejahtera; (4) Hasil penelitian Yusup, Pawit M.; Rahmawati, Tine Silvana; dan Subekti, Priyo (2014) dengan judul makna miskin menurut pandngan orang miskin pedesaan; (5) Hasil penelitian Yusup, Pawit M.; Subekti, Priyo; Anwar, Rully Khairul (2014) dengan tema ujicoba berwirausaha berbasis membaca pustaka secara terdampingi; 
(6) Hasil penelitian Iwan Hermawan (2012) yang meneliti pemberdayaan penduduk miskin di pedesaan; (7) Hasil penelitian Lestari, Syahnaz Yuliana; Komariah, Neneng; dan Rizal, Edwin (2016) dengan tema Pengelolaan informasi; (8) Hasil penelitian yang dilakukan oleh Nashihuddin, Wahid dan Tupan dari PDII LIPI pada tahun 2016 (Nashihuddin, Wahid dan Tupan, 2016: 95-107), dengan tema Manajemen Layanan Kemas Ulang Informasi Digital di PDII LIPI. Inti dari kajian ini adalah pada gagasan kreatif tentang layanan inovasi berupa pengemasan ulang informasi digital bagi pengguna atau masyarakat yang menggunakannya.

Sejumlah pustaka tersebut penulis gunakan untuk bahan analisis dan pembahasan mengenai tema kemiskinan pedesaan yang umumnya berciri pertanian tradisional. Konteks desa tani, penduduk miskin, sistem usaha bersama lumbung padi sebagai bagian dari bentuk usaha koperasi, dan adanya proaktivitas layanan perpustakaan desa yang berorientasi kewirausahaan, semuanya mewarnai kehidupan dan sekaligus penghidupan penduduk pedesaan yang berkarakter pertanian tradisional.

\section{METODE PENELITIAN}

Metode yang digunakan adalah observasi lapangan ke beberapa desa di Kecamatan Pamarican dan Kecamatan Banjarsari Kabupaten Ciamis, Jawa Barat. Adapun teknik pengambilan datanya adalah dengan melakukan pengamatan langsung kondisi dan situasi desa dan wawancara dengan para pengurus desa dan perpustakaan yang ada di desa.

Langkah-langkah metodologis yang dilakukan dalam penelitian lapangan menurut Lofland (dalam Baiyey, 1987), terutama dalam mencatat data lapangan, yakni: 1) mendeskripsikan hal-hal atau peristiwa yang sedang berlangsung; 2) mendeskripsikan dan mencatat peristiwa yang telah berlangsung; 3) menganalisis ide-ide yang muncul dan perkaya dengan inferensi; 4) mencatat kesan-kesan dan perasaan orang perorangan; dan membuat catatan untuk informasi lebih lanjut. Pada setiap langkah ini, peneliti sekaligus melakukan wawancara, diskusi, dan konfirmasi tentang aspek-aspek yang sedang berlangsung, dengan tema terfokus pada: (a) diskusi dan wawancara dengan pengurus desa dan pemuka masyarakat mengenai informasi awal tentang peta permasalahan kemiskinan pedesaan dilihat dari aspek penyediaan sarana pelatihan usaha berbasis membaca sumber-sumber informasi kewirausahaan; (b) belajar melalui diskusi dan wawancara bersama masyarakat miskin pedesaan mengenai potensi usaha di desa atas dasar pandangan dan pengalaman mereka; (c) menyusun model usaha berbasis pemanfaatan sumber bacaan yang cocok dengan jenis usaha di desa; (d) diskusi mengenai rintisan penyelenggaraan kelompok usaha berbasis Lumbung Padi di desa, yang terbukti bisa tahan terhadap perubahan global; dan (e) mensinergikan semua kegiatan yang dilakukan oleh masing-masing unsur di atas

Langkah selanjutnya adalah menyusun hasil penelitian dari pengamatan langsung ke lapangan. Berdasarkan perspektif outcomes (hasil) pengamatan lapangan ini, pengetahuan yang dirumuskannya bersifat hipotetik yang dibangun berdasarkan pola hubungan tertentu antar aspek dalam situasi dan realitas sosial. Dalam prakteknya, jika diperlukan, nantinya peneliti bisa membangun hipotesis kerja, atau setidaknya berupa proposisi yang digunakan untuk memahami konteks dan waktu, yang dalam konteks tertentu dikenal dengan istilah konstruk derajat kedua menurut pandangan Schutz (1967) dan juga Mulyana, (2002: 172). Konsepsi ini lebih merupakan sebagai semacam kerangka teoretis yang dibangun peneliti berdasarkan data hasil penelitian lapangan. Hasilnya bukan sekadar narasi hasil pengamatan subjek dan objek di lapangan, namun sudah mengarah ke bentuk-bentuk proposisi temuan penelitian awal. Proposisiproposisi inilah yang kemudian dijadikan bahan untuk menyusun kategorisasi hasil penelitian lapangan secara lebih komprehensif.

Dalam kondisi tertentu, tahapan kegiatan seperti dikemukakan di atas dilakukan secara pendampingan oleh tim penelitian. Tim peneliti secara langsung menginisiasi, memandu, memfasilitasi, menyediakan, dan melakukan pengumpulan data dan informasi yang 
diperlukan untuk kepentingan pengembangan ilmu pengetahuan dan teknologi yang bermanfaat bagi masyarakat ilmiah dan awam. Dalam prakteknya di setiap tahapan kegiatan, tim melakukan analisis data terkait dengan permasalahan pada saat itu, kemudian berusaha memecahkannya, menganalisisnya, dan menyusunnya untuk dijadikan draf artikel yang disubmit ke jurnal, baik internasional, nasional terakreditasi, ataupun jurnal nasional ber-ISSN. Hal ini bergantung kepada kandungan nilai dari permasalahan dimaksud. Jika permasalahan mengandung nilai yang berskala nasional, maka artikelnya akan disubmit ke jurnal internasional bereputasi. Jika inti permasalahannya memiliki kandungan lokal namun bisa berguna bagi masyarakat secara nasional, maka artikel hasil susunannya akan disubmit ke jurnal nasional terakreditasi. Demikian pula jika inti permasalahan hanya berlaku untuk penduduk dengan skala lokal, maka artikel susunannya akan disubmit ke jurnal nasional ber-ISSN .

Langkah-langkah penelitian di atas, digambarkan sebagai satu lingkaran kehidupan dan penghidupan di pedesaan yang bertumpu pada seektor pertanian tradisional. Gambaran hasil penelitian ini nantinya berupa hubungan harmoni desa tani, penduduk miskin, lumbung padi, dan fasilitas belajar bersama berupa perpustakaan desa. Semua komponen kegiatan ini secara sinergis dikerjakan oleh para pengurus masing-masing kelompok usaha, dengan tetap didampingi oleh tim penelitian dan pengabdian kepada masyarakat dari Universitas padjadjaran. Sedangkan sistem pengelolaannya setelah penelitian mendalam selesai dilakukan, sepenuhnya diserahkan kepada para pengurus kelompok usaha di bawah koordinasi dan tanggung jawab kepala desa.

Lokasi penelitian secara keseluruhan adalah desa-desa di Jawa Barat Bagian Selatan, yang meliputi Kabupaten Ciamis, Kabupaten Tasikmalaya, Kabupaten Garut, Kabupaten Cianjur, dan Kabupaten Sukabumi. Namun untuk ujicoba pelaksanaan sistem harmoni desa tani kaitannya dengan penduduk miskin, sistem usaha lumbung padi dan model layanan implementatif yang dikreasi oleh perpustakaan desa, penelitian difokuskan pada Kecamatan
Pamarican dan Kecamatan Banjarsari Kabupaten Ciamis.

\section{HASIL DAN PEMBAHASAN}

Tidak dapat dipungkiri bahwa kondisi masyarakat pedesaan yang umumnya bekerja sebagai petani dan buruh serabutan di sektor pertanian tradisional, relatif lebih mampu bertahan terhadap goncangan perubahan global saat ini. Bahkan di tingkat lokal dan nasional, seperti contohnya ketika di Indonesia pada kurun waktu tahun 1998 terjadi krisis ekonomi yang kemudian merambat menjadi krisis multidimensional, kondisi masyarakat pedesaan tampak tidak terlalu merasakan dampaknya secara langsung. Mereka tetap eksis, bisa tetap bertahan, dan tetap bekerja seperti biasa. Kondisi yang sangat berbeda dirasakan oleh kelompok msyarakat perkotaan yang umumnya berbasis pada pekerjaan sebagai pedagang, buruh tetap, dan pengusaha lainnya. Mereka sangat terkena dampak krisis ekonomi pada saat itu. Bahkan sisa-sisa dampaknya masih ada hingga sekarang. Perusahaan kecil, menengah, bahkan besar, banyak yang bangkrut, dan hingga sekarang tidak pernah bangkit lagi.

Sebagai contoh. Ketika harga BBM (bahan bakar minyak) dinaikkan oleh pemerintah, kehidupan kota banyak terganggu oleh hirukpikuk mereka yang melakukan demo (demonstrasi, unjuk rasa), namun masyarakat di desa tetap "adem ayem" (tenang). Seolah tidak terpengaruh oleh adanya perubahan harga kebutuhan pokok yang terjadi sebagai dampak dari kenaikan harga minyak bumi, warga desa tetap tenang, tetap berkehidupan seperti biasa, tidak terjadi gejolak yang mengganggu keamanan. Untuk beberapa orang atau kelompok tertentu seperti petani sayur, buah, dan petani palawija, misalnya, justru "diuntungkan" dengan adanya kenaikan harga hasil buminya di pasaran.

Kondisi kehidupan desa yang tetap harmoni dalam segala aspeknya, juga tampak jelas jika dilihat dari sisi hubungan sosial antar penduduknya. Mereka tetap bersosialisasi tanpa ada kegaduhan sosial yang berarti. Penduduk yang berkategori bukan miskin, tetap menjalankan roda kehidupannya, tetap 
menjalankan penghidupannya. Demikian juga dengan penduduk yang berkategori miskin. Mereka tetap bekerja seperti biasa. Hubungan antara kelompok kaya dan miskin juga tetap bersimbiosis mutualis, saling mengisi kekurangan.

Kondisi kehidupan yang tetap tenang di desa tampaknya bukan tidak ada sebabnya. Banyak ahli telah menjelaskan dengan berbagai pendekatan dan sudut pandang masing-masing. Beragam teori pun banyak digunakan untuk menjelaskan berbagai konteks kehidupan dan penghidupan di desa, terutama kehidupan dan penghidupan kelompok miskin yang tampak seperti tidak mengalami goncangan yang berarti dalam situasi perubahan global saat ini. Beberapa kepustakaan berikut mencoba menjelaskan kondisi harmoni sosial di kehidupan sosial pedesaan:

Hasil penelitian Yusup, Pawit M.; Rahmawati, Tine Silvana; Subekti, Priyo (2013:21-28), yang meneliti tentang peta lingkup informasi penghidupan orang miskin pedesaan. Hasilnya menggambarkan bahwa, jenis kebutuhan utama orang miskin pedesaan terdiri atas kebutuhan pangan, sandang, papan, kesehatan, dan pendidikan yang sangat sederhana. Selain itu, beragam informasi penghidupan yang dicari oleh orang miskin pedesaan yang sifat pekerjaannya serabutan, berasal dari sumber orang secara interpersonal yang bersifat informal, dengan lingkup yang terbatas. Terbatas dalam hal ini meliputi selingkaran tetangga, kerabat, pelanggan, dan sesama pekerja sejenis. Sumber dan saluran yang berasal dari media resmi dan yang berbasis teknologi, hampir tidak pernah digunakan, dan unsur-unsur formal yang datangnya dari sisi pemerintah, hampir tidak menyentuh kepentingan orang-orang miskin pedesaan. Terkait dengan kondisi seperti ini, mereka mengaku sering ketinggalan informasi tentang penghidupan yang seharusnya bisa mereka lakukan.

Berikutnya adalah hasil penelitian Yusup, Pawit M. (2013), dengan tema memetakan jenis kebutuhan utama orang miskin pedesaan dan variasi jenis informasi penghidupan yang dicarinya. Hasilnya menggambarkan bahwa jenis kebutuhan utama orang-orang miskin pedesaan terdiri atas pangan, sandang, papan, kesehatan, dan pendidikan yang amat sederhana; beras murah, pakaian sederhana, rumah sederhana, sehat fisik, dan kalaupun sakit bisa berobat murah bahkan gratis, serta anakanak bisa sekolah sampai tingkat lanjutan. Kebutuhan mereka tampak amat sederhana. Hampir tidak ada motivasi untuk menggapai harapan yang terlalu tinggi, karena takut gagal. Hal ini diperkuat dengan pernyataan Pain, salah seorang informan penelitian ini yang mengemukakan, "saya tidak perlu mematok kebutuhan yang terlalu tinggi, percuma, yang penting diberi sehat, maka bisa makan".

Selanjutnya adalah hasil penelitian Yusup, Pawit M. dan Neneng Komariah (2013), dengan jusul Dimensi Pencarian Dan Penggunaan Informasi Kesehatan Pada Keluarga Prasejahtera di Kabupaten Bandung: Studi Tentang Pemetaan Terhadap Kebutuhan, Pencarian, dan Penggunaan Informasi Kesehatan pada Keluarga Prasejahtera di Kecamatan Rancaekek Kabupaten Bandung. Hasil penelitian ini menggambarkan secara "mapping" (pemetaan) terhadap perilaku pencarian dan penggunaan informasi kesehatan di kalangan keluarga prasejahtera (keluarga miskin) di Kabupaten Bandung. Hasil penelitian menggambarkan bahwa: dilihat dari dimensi pencarian informasi kesehatan, yang paling menonjol adalah mengenai cara pencariannya yang dilakukan secara aktif dan pasif dengan sumber dan saluran informasi interpersonal yang bersifat informal. Dilihat dari dimensi penggunaan informasi kesehatan, yang paling menonjol adalah pada jenis informasi kesehatan yang bersumber pada ahli kesehatan terpilih, dan juga dari tetangga dan keluarga. Penduduk miskin hampir tidak ada yang menggunakan informasi yang bersumber dari media, baik cetak maupun elektronik.

Berikutnya adalah hasil penelitian Yusup, Pawit M.; Rahmawati, Tine Silvana; dan Subekti, Priyo (2014: 88). Tema kajiannya adalah makna miskin menurut pandngan orang miskin pedesaan. Hasilnya menggambarkan bahwa makna miskin dan kemiskinan, secara fenomenologi, mengandung konteks, seperti: konteks kepemilikan; konteks upaya dan coba- 
coba; konteks ketidakberdayaan; konteks bantuan pihak luar; konteks kemandirian dalam keterpaksaan; konteks harapan yang tidak tergapai; konteks perjuangan; konteks keterbatasan akses informasi; konteks keingintahuan yang rendah; konteks kesederhanaan kebutuhan; konteks masalah keterhinaan; dan konteks kepekaan dalam komunikasi sosial.

Sementara itu, hasil penelitian yang masih terkait dengan tema penelitian ini adalah ujicoba berwirausaha berbasis membaca pustaka secara terdampingi. Kegiatan-kegiatan usaha yang dilakukan penduduk desa secara kelompok di desa, akan lebih berhasil jika disertai dengan sistem pendampingan yang dilakukan oleh pihak luar, terutama dari perguruan tinggi melalui kegiatan penelitian tindakan dan pelaksanaan pengabdian kepada masyarakat (Yusup, Pawit M.; Subekti, Priyo; Anwar, Rully Khairul (2014:20).

Pustaka lain dari hasil penelitian Rosfiantika, Evi dan Yusup, Pawit M. (2015:153-160), mengembangkan tema penelitian yang berfokus pada implementasi membaca melalui pemanfaatan perpustakaan masjid. Dalam hal ini, perpustakaan masjid dipandang sebagai perpustakaan komunitas. Hasilnya menggambarkan bahwa Perpustakaan Masjid bisa dijadikan sarana, fasilitas, dan media pembelajaran para jamaah masjid melalui kegiatan membaca bahan bacaan berkonten pengetahuan umum dan keagamaan. Para jamaah masjid menjadi termotivasi untuk menyempatkan diri membaca buku dan bahan bacaan lain yang disediakan oleh Perpustakaan Masjid. Dalam beberapa situasi, dilakukan berbagai kegiatan pelatihan berbasis implementasi hasil membaca yang difasilitasi oleh perpustakaan masjid.

Pustaka lainnya adalah dari Iwan Hermawan yang meneliti pemberdayaan penduduk miskin di pedesaan. Dikemukakan bahwa dilihat dari sisi pemerintah, misalnya, sudah banyak program yang bertujuan untuk mengurangi angka kemiskinan di pedesaan. Beberapa di antaranya adalah: (1) program Penyelia Mitra Tani (PMT) untuk Pengembangan Usaha Agribisnis Perdesaan (PUAP) dan Lembaga
Mandiri yang Mengakar di Masyarakat (LM3), (2) dana Bantuan Langsung Masyarakat (BLM) sebesar Rp. 100 juta/gapoktan/ desa. Pada tahap awal di arahkan untuk mendukung usaha produktif usaha agribisnis di perdesaan. Untuk selanjutnya, didorong sebagai modal dasar dalam pengembangan usaha simpan pinjam dan Lembaga Keuangan Mikro (LKM), dan (3) dana bantuan sosial yang diberikan kepada LM3 antara Rp. 70 Juta - Rp. 300 juta per LM3. (Hermawan, 2012: 140).

Hasil penelitian lainnya dari Yusup, Pawit M.; Rohanda; dan Subekti, Priyo (2015), yang sudah diseminarkan dengan lingkup nasional dan telah diterbitkan pada Prosiding Kepustakawanan Indonesia (2015: 297). Hasilnya menggambarkan bahwa, setiap kegiatan yang bertujuan untuk membantu orang miskin keluar dari kondisinya selama ini, perlu ada kegiatan yang langsung menyentuh kepentingan mereka. Caranya antara lain dengan memberi ruang kepada anak-anak mereka supaya bisa melanjutkan sekolah ke jenjang yang lebih tinggi. Salah satunya adalah pembebasan biaya sekolah, pemberian beasiswa, dan penyediaan fasilitas belajar bersama di setiap desa. Penyediaan fasilitas belajar bersama ini juga bisa disediakan di tempat-tempat yang strategis, seperti Perpustakaan Desa, TBM, Rumah Pintar, dan fasilitas belajar sejenisnya. Fasilitas belajar ini lebih berarti jika secara langsung prioritasnya diperuntukkan bagi kelompok-kelompok masyarakat di desa yang berkategori miskin.

Pustaka berikut yang menarik untuk dikemukakan di sini adalah hasil penelitian Lestari, Syahnaz Yuliana; Komariah, Neneng; dan Rizal, Edwin (2016: 59) dengan tema Pengelolaani nformasi Sebagai Upaya Memenuhi Kebutuhan Informasi Masyarakat. Salah satu hasilnya menggambarkan tentang upaya yang dilakukan oleh Dinas Komunikasi dan Informatika Kabupaten Garut dalam mengelola informasi untuk memenuhi kebutuhan informasi bagi masyarakat. Beberapa langkah pentingnya antara lain adalah: memproses data menjadi informasi yang dibutuhkan masyarakat, mengumpulkan dan menganalisis informasi, menyajikan informasi 
dalam berbagai bentuk sajian, menyimpan dan mendokumentasikan informasi dalam berbagai bentuk media penyimpanan guna memudahkan pemanfaatan kembali informasi dimaksud di masa yang akan datang. Intinya, Dinas Komunikasi dan Informatika sebagai salah satu bentuk lembaga pelayanan publik, berupaya agar informasi bisa sampai kepada masyarakat yang membutuhkan.

Sebetulnya banyak cara yang bisa dilakukan oleh lembaga layanan publik. Salah satu contoh yang menarik adalah pustaka hasil penelitian yang dilakukan oleh Nashihuddin, Wahid dan Tupan dari PDII LIPI pada tahun 2016 (Nashihuddin, Wahid dan Tupan, 2016: 95107). Dengan tema Manajemen Layanan Kemas Ulang Informasi Digital di PDII LIPI, yang berkreasi menggagas layanan inovasi berupa pengemasan ulang informasi digital bagi pengguna atau masyarakat yang menggunakannya. Salah satu hasilnya adalah bahwa sebagian besar pengguna jasa pusdokinfo lebih menyukai informasi yang praktis dan terjangkau dalam bentuk digital untuk memenuhi kebutuhan informasinya.

Hasil lain dari penelitian ini adalah bahwa, miskin itu identik dengan orang yang selalu ketinggalan informasi. Disarankan bahwa, setiap kegiatan yang dilakukan terkait dengan tema miskin, hendaknya memperhatikan kondisi ini. Salah satu caranya adalah dengan melakukan kegiatan yang bisa meliterasiinformasi mereka, dengan cara antara lain, memulai menyediakan media dan sumbersumber belajar bersama, membangun Perpustakaan Desa, membangun TBM, menyelenggarakan Rumah Pintar, membina komunitas membaca dan berusaha, dan kegiatan lain yang bisa dan biasa dilakukan oleh pustakawan dan ilmuwan perpustakaan dan informasi, termasuk oleh pihak pergutuan tinggi melalui program tridarmanya, khususnya bidang pengabdian kepada masyarakat.

\section{Kelompok usaha berbasis kebersamaan}

Dari berbagai hasil penelitian seperti dikemukakan, tampak jelas bahwa penduduk miskin pedesaan, yang umumnya bekerja sebagai petani penggarap atau buruh serabutan di sektor pertanian di pedesaan, memiliki kekhasannya sendiri. Mereka hidup dengan penghidupan yang amat sederhana di hampir semua aspeknya. Mereka bisa tetap mampu bertahan hidup dengan kondisi yang amat sederhana, namun tetap bisa bersosialisasi dengan penduduk lainnya, baik yang tergolong miskin atau kaya. Suasana seperti inilah yang membuat banyak pengamat dan para ahli mendeskripsikannya secara humanis dan arif.

Sistem usaha berprinsip kebersamaan yang banyak berlaku di desa adalah koperasi dan kelompok-kelompok usaha berbasis pertanian. Salah satunya adalah pengelolaan Kelompok Arisan Padi, model Lumbung Desa, Lumbung Padi, atau Lumbung Paceklik. Lumbung desa didirikan dengan pertimbangan kehidupan sosial ekonomi masyarakat pedesaan yang penghidupannya banyak bertumpu pada bidang pertanian. Sektor ini sangat dipengaruhi perubahan iklim. Ketika suatu saat iklim tak mendukung, misalnya terjadi musim kemarau panjang, banjir, hama penyakit, dan kejadian lain yang bisa menimbulkan rawan pangan di suatu daerah, maka kehadiran lumbung padi ini sangat bisa menjadi "penyelamat" kehidupan penduduk desa. Namun demimian, seperti pernah dikemukakan oleh Kades Sukamukti (hasil wawncara pada tahun 2015), "tidak mudah memang untuk membangun sistem usaha lumbung padi ini karena berbagai faktor", terutama faktor para pelaku (anggota) yang masih perlu sepenuhnya menyadari akan manfaat lumbung padi ini.

Dalam kehidupan sekarang, konsep lumbung padi tidak hanya sekadar gudang penyimpan padi dan bahan makanan pokok lain sebagai cadangan makanan warga desa di saat paceklik. Namun sudah bergeser menjadi semacam koperasi atau kelompok usaha penduduk setempat yang "core business'-nya pertanian, terutama padi. Dalam prakteknya, komoditas usaha model koperasi lumbung padi ini bisa dilengkapi dengan komoditas lainnya yang masih termasuk hasil bumi.

Satu sisi kehidupan lain yang bisa mendukung sistem usaha berbasis lumbung paceklik ini, adalah sektor pendidikan masyarakat desa secara keseluruhan. Semua 
penduduk desa tanpa kecuali, memiliki hak yang sama untuk mendapatkan pendidikan yang memadai, baik melalui jalur formal maupun non formal (pendidikan luar sekolah). Dalam hal yang terakhir inilah kehadiran perpustakaan menjadi penting. Untuk wilayah pedesaan, kehadiran perpustakaan desa menjadi bagian dari kehidupan masyarakat yang selalu menginginkan penambahan pengetahuan dan keterampilannya. Perpustakaan Desa, misalnya, bisa menjadi fasilitator kegiatan pendidikan dan pelatihan anggotanya terkait penghidupan mereka. (Hasil diskusi bersama sejumlah tokoh masyarakat dan pengurus perpustakaan desa berbasis pendidikan islam di desa Sukamukti kecamatan Pamarican Kabupaten Ciamis, Jawa Barat, pada bulan April 2015).

Kelompok-kelompok kegiatan dan usaha di desa akan tetap bisa berkembang seiring dengan adanya unsur masyarakat desa yang memfasilitasi penyediaan informasi dan sumber-sumber informasi untuk mendukung perkembangannya. Dalam kondisi seperti ini, perpustakaan desa hadir untuk mengisi aspekaspek teknis terkait dengan penyelenggaraan kegiatan diskusi dan pembelajaran bersama, kegiatan pelatihan dan kegiatan lain yang tujuannya untuk meningkatkan kemampuan anggota masyarakat dalam berwirausaha, baik secara kelompok maupun secara perseorangan.

Menghidupkan kembali sistem lumbung padi di desa memang memerlukan semangat kegotongroyongan sejumlah penduduk desa, keterlibatan dan ketegasan pamong desa, dan anggota masyarakat lainnya yang secara aktif menjadi anggotanya. Sistem lumbung desa selama ini lebih banyak diinisiasi oleh pihak eksternal, yang bersifat top down, sehingga rasa kepemilikannya menjadi kurang. Jika inisiasi dilakukan oleh masyarakat desa yang tergabung dalam kelompok usaha sistem lumbung padi atau desa, tampaknya hasilnya lebih bisa bertahan lama, apalagi jika sistem ini diintegrasikan dengan model layanan perpustakaan desa secara implementatif kepada masyarakat kelompok tertentu yang memerlukan bantuan. Penduduk miskin akan merasa tertolong dan dihargai dengan hadirnya sistem usaha lumbung padi atau lumbung desa atau lumbung paceklik ini.

Semua data hasil penelitian pendahuluan yang didasarkan atas observasi dan wawancara dengan informan, disusun ke dalam model harmoni desa tani, penduduk miskin, lumbung padi, dan perpustakaan desa, seperti tampak dalam Gambar 1.

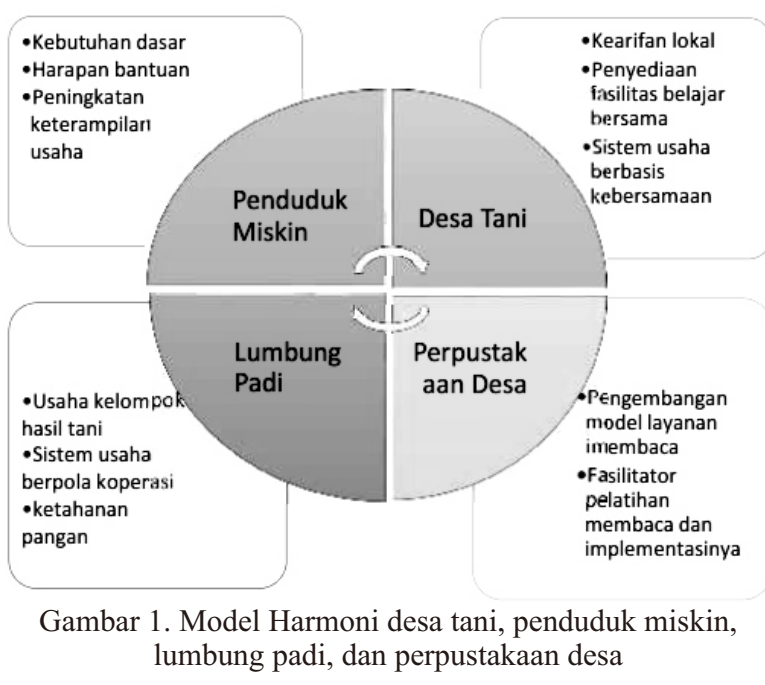

Ada empat unsur pokok dalam Gambar 1, yakni unsur penduduk miskin dengan karakteristiknya yang bertumpu pada aspek pemenuhan kebutuhan dasar atau kebutuhan pokok, memiliki perasaan berharap mendapatkan bantuan dari orang lain, dan keinginan untuk meningkatkan keterampilan dalam mencari nafkah. Sementara itu unsur berikutnya adalah kondisi pedesaan yang berkarakter pertanian pedesaan, atau disebut dengan unsur desa tani, dengan ciri memiliki kearifan lokal, memiliki sistem kehidupan berbasis kebersamaan, dan adanya keinginan untuk saling berbagi dalam usaha bersama secara kekeluargaan. Unsur berikutnya adalah sistem usaha bersama dalam bentuk lumbung padi, yakni semacam usaha berbasis koperasi yang mengandalkan komoditas hasil pertanian khususnya padi. Jenis usaha seperti ini lebih banyak bersifat sosial kebersamaan, dan berfungsi sebagai penopang sediaan pangan di saat paceklik. Sedangkan unsur yang terakhir adalah keberadaan fasilitas pembelajaran penduduk miskin berupa perpustakaan desa dan atau perpustakaan 
masyarakat yang orientasi layanannya pada penyediaan koleksi buku dan sumber-sumber informasi tentang teknologi tepat guna atau kewirausahaan yang sesuai dengan kondisi desa tani.

Melalui layanan implementatif dan pendampingan usaha berbasis membaca yang diinisiasi oleh perpustakaan desa bekerja sama dengan perguruan tinggi dan unsur terkait lainnya yang relevan, para penduduk miskin di desa diberi pelatihan usaha sesuai dengan pilihan minatnya. Misalnya, mereka yang meminati bidang pemeliharaan ikan lele dumbo, sebagai contoh, akan disediakan fasilitas bahan bacaan tentang budidaya lele dumbo. Demikian pula dengan mereka yang meminati bidang usaha budidaya burung puyuh, misalnya, maka akan disediakan bahan-bahan bacaan mengenai budidaya burung puyuh.

Para peminat usaha sesuai dengan pilihan di atas, dalam prakteknya didampingi oleh tim penelitian dan pengabdian kepada masyarakat (PKM) dari perguruan tinggi, dalam hal ini dari Universitas Padjadjaran. Semua kegiatan pelatihan usaha yang disertai dengan pendekatan pendampingan ini, idealnya diinisiasi oleh perpustakaan desa dan atau perpustakaan masyarakat yang ada di desa, melalui beragam implementasi layanannya. Rintisan praktik layanan implementatif perpustakaan desa dan perpustakaan masyarakat yang ada di desa, pernah dilakukan oleh tim Peneliti dan PKM dari Universitas Padjadjaran di Desa Sukamukti Kecamatan Pamarican Kabupaten Ciamis, Jawa Barat pada kurun waktu 2014 (Lihat: Yusup, Pawit M.; Subekti, Priyo; dan Anwar, Rully Khairul (2014). Kegiatan seperti ini masih berlanjut hingga sekarang, bahkan direncanakan akan ditingkatkan intensitasnya pada tahun-tahun mendatang. Tabel 1 menggambarkan adanya pencapaian hasil kegiatan yang dilakukan oleh model layanan implementasi hasil membaca ini yang dilakukan oleh Perpustakaan Desa. Hasilnya ada perbedaan antara sebelum dan sesudah dilakukannya kegiatan implementasi layanan implementasi hasil membaca yang difasilitasi oleh perpustakaan desa.

Secara ringkas, langkah-langkah layanan
Tabel 1. Capaian Kegiatan Implementasi Layanan Perpustakaan Desa

\begin{tabular}{|c|c|}
\hline Sebelum Kegiatan & Setelah Kegiatan \\
\hline $\begin{array}{l}\text { Perpustakaan Desa belum } \\
\text { tersedia di desa. Layanan } \\
\text { perpustakaan lain juga tidak } \\
\text { sampai ke lokasi desa. }\end{array}$ & $\begin{array}{l}\text { Ada rintisan penyelenggaraan } \\
\text { perpustakaan desa secara } \\
\text { sederhana. Sekitar } 300 \text { buku } \\
\text { kategori TTG (Teknologi } \\
\text { Tepat Guna) disediakan. }\end{array}$ \\
\hline $\begin{array}{l}\text { Sebagian besar penduduk miskin } \\
\text { di desa tidak memiliki } \\
\text { keterampilan membaca yang } \\
\text { diaplikasikan hasilnya. Buku } \\
\text { buku berkategori TTG juga } \\
\text { belum dikenal luas oleh sebagian } \\
\text { besar penduduk desa. }\end{array}$ & $\begin{array}{l}\text { Di antara penduduk miskin } \\
\text { pedesaan, sudah mulai ada } \\
\text { beberapa orang yang yang } \\
\text { menyadari dan mencoba } \\
\text { mengaplikasikan hasil dari } \\
\text { membaca bahan bacaan } \\
\text { tertentu, terutama buku } \\
\text { berkategori TTG, terutama } \\
\text { setelah dilakukan kegiatan ini. }\end{array}$ \\
\hline $\begin{array}{l}\text { Layanan Perpustakaan Desa lain } \\
\text { tidak sampai ke desa tempat } \\
\text { kegiatan. }\end{array}$ & $\begin{array}{l}\text { Beberapa orang penduduk desa } \\
\text { sudah merasakan adanya } \\
\text { manfaat kegiatan layanan } \\
\text { membaca buku -buku TTG } \\
\text { secara implementatif yang } \\
\text { diinisiasi oleh tim PKM Unpad } \\
\text { melalui rintisan } \\
\text { penyelenggaraan Perpustakaan } \\
\text { Desa. }\end{array}$ \\
\hline Belum ada model layanan & Ada model layanan \\
\hline Perpustakaan Desa yang secara & implementatif buku-buku TTG \\
\hline khusus mengimplementasikan & yang dilakukan oleh tim \\
\hline hasil membaca buku -buku TTG & kegiatan PKM berbasis \\
\hline $\begin{array}{l}\text { secara terdampingi kepada } \\
\text { sekelompok penduduk miskin di } \\
\text { pedesaan. }\end{array}$ & $\begin{array}{l}\text { layanan Perpustakaan Desa } \\
\text { secara pendampingan terhadap } \\
\text { kelompok penduduk miskin di } \\
\text { pedesaan. }\end{array}$ \\
\hline $\begin{array}{l}\text { Belum pernah ada pelatihan } \\
\text { produksi aneka kue dan } \\
\text { pembuatan telor asin untuk }\end{array}$ & $\begin{array}{l}\text { Sudah dilakukan pelatihan } \\
\text { produksi aneka kue dan } \\
\text { pembuatan telor asin untuk }\end{array}$ \\
\hline $\begin{array}{l}\text { dipasarkan ke warung -warung } \\
\text { dan pasar tradisional yang } \\
\text { dilakukan oleh kelompok ibu }\end{array}$ & $\begin{array}{l}\text { dipasarkan ke warung -warung } \\
\text { dan pasar tradisional yang } \\
\text { dilakukan oleh kelompok }\end{array}$ \\
\hline $\begin{array}{l}\text { rumah tangga dari keluarga } \\
\text { miskin di desa. }\end{array}$ & $\begin{array}{l}\text { remaja, pemuda, dan ibu -ibu } \\
\text { rumah tangga dari keluarga } \\
\text { miskin di desa secara } \\
\text { terdampingi. }\end{array}$ \\
\hline $\begin{array}{l}\text { Banyak kegiatan penduduk di } \\
\text { desa yang tidak produktif, banyak } \\
\text { membuang waktu yang tidak } \\
\text { seharusnya, tidak membaca }\end{array}$ & $\begin{array}{l}\text { Ada perubahan dalam mengisi } \\
\text { waktu luang, dari tidak } \\
\text { membaca menjadi membaca. } \\
\text { Mengisi waktu luang dengan } \\
\text { membaca buku dan bahan } \\
\text { bacaan lain yang disediakan } \\
\text { oleh Perpustakaan Desa. }\end{array}$ \\
\hline $\begin{array}{l}\text { Sampai tahun 2014, di desa } \\
\text { Sukamukti Kecamatan Pamarican } \\
\text { Kabupaten Ciamis, Jawa Barat, } \\
\text { belum ada Perpustakaan Desa. }\end{array}$ & $\begin{array}{l}\text { Mulai tahun } 2015 \text {, di desa ini } \\
\text { sudah ada rintisan } \\
\text { penyelenggaraan perpustakaan } \\
\text { desa, yang orientasinya adalah } \\
\text { memfasilitasi kelompok } \\
\text { masyarakat yang ingin } \\
\text { berwirausaha sesuai dengan } \\
\text { pilihan minatnya. }\end{array}$ \\
\hline
\end{tabular}

implementatıf $1 \mathrm{n} 1$ adalah sebaga berıkut: (1) Mendata dan memastikan bahwa di desa tempat dilakukan kegiatan, belum tersedia fasilitas belajar bersama berupa Taman Bacaan Masyarakat (TBM) ataupun Perpustakaan Desa. (2) Langkah selanjutnya adalah melakukan pembelajaran bersama masyarakat dalam bentuk diskusi dan konsultasi mengenai tema- 
tema usaha berbasis memanfaatkan bahan bacaan yang disediakan oleh Perpustakaan Desa. (3) Selanjutnya tim berusaha menyediakan sejumlah buku dan bahan bacaan lain yang berisi mengenai TTG yang sesuai dengan kondisi desa. (4) Langkah berikutnya adalah melakukan diskusi terfokus mengenai aspek-aspek usaha yang bisa dilakukan di desa dengan kelompok sasaran terseleksi, seperti remaja putus sekolah, kelompok ibu rumah tangga, dan kelompok lain yang berminat dalam berusaha, baik secara sambilan (paruh waktu) maupun secara tetap. (5) Memilih jenis usaha didasarkan atas pilihan peserta, dengan pertimbangan bisa ditekuni dan bisa berpeluang mendapatkan tambahan penghasilan. (6) Semua kegiatan dari langkah-langkah di atas dilakukan secara pendampingan oleh tim penelitian dan tenaga ahli yang ditunjuk oleh tim peneliti. (7) Langkah berikutnya adalah melakukan langkah uji coba mengimplementasikan isi bacaan yang disediakan oleh Perpustakaan Desa dengan kelompok sasaran terpilih. (8) Langkah terakhir dari kegiatan implementasi layanan berwirausaha berbasis memanfaatkan Perpustakaan Desa ini adalah melakukan evaluasi terhadap para peserta kegiatan dan sekaligus mengevaluasi atas kinerja tim penelitian secara keseluruhan. Jika semua langkah tersebut dilaksanakan sesuai dengan prosedur seperti itu, diharapkan bisa mendapatkan hasil yang nyata pada kehidupan peserta yang berasal dari kelompok masyarakat miskin di desa. Setidaknya, para peserta mendapatkan pembelajaran umum mengenai aspek-aspek kewirausahaan yang bisa dikembangkan di desa.

Kehadiran Perpustakaan Desa memang bukan satu-satunya unsur yang berperan dalam pembangunan masyarakat desa, namun setidaknya perpustakaan sudah berkiprah secara langsung dalam pembangunan di desa. Salah satu kegiatannya adalah mengembangkan model layanan implementasi hasil membaca untuk tujuan berwirausaha bagi kelompok masyarakat miski di desa. Indikator keberhasilannya secara umum seperti tampak pada Tabel 1.
Sebagai contoh kasus, kelompok usaha yang berbasis membaca atau memanfaatkan Perpustakaan Desa yang dijadikan subjek kegiatan ini adalah Dewi Catering, AdiCom, dan Kawitan. Ketiga kelompok usaha yang pertama, Dewi Catering, sesuai dengan namanya, bergerak dalam bidang produksi aneka makanan kering yang dipasarkan lewat warung-warung tradisional di desa. Kelompok ini memiliki anggota yang terdiri atas ibu-ibu rumah tangga di desa. Kelompok usaha berikutnya, AdiCom, adalah kelompok usaha yang pesertanya terdiri atas sejumlah remaja dan pemuda yang hampir semuanya putus sekolah, bergerak dalam bidang internet marketing. Kelompok usaha ini bahkan pada tahun 2017 sudah memiliki jumlah anggota sebanyak 30 orang. Bahkan, kelompok usaha ini sekarang sudah memperluas jaringan usahanya ke arah fashion, mulai membuka toko pakaian dengan cara memasarkannya cerala langsung dan lewat online. (Hasil wawancara dan observasi di Desa Sukamukti pada tanggal 16 Agustus 2017). Sedangkan kelompok ketiga adalah Kawitan, yang bergerak dalam bidang usaha produksi jajanan dan pembuatan aneka kue basah untuk dipasarkan di warung-warung tradisional di desa. Ke depan, jenis usaha ini bisa dikembangkan pemasarannya melalui kerja sama dengan rumah makan, toko kue, dan mallmall terdekat.

Intinya, perpustakaan Desa bukan hanya sebatas tempat tersedianya sejumlah buku dan bahan bacaan lain untuk kepentingan membaca. Perpustakaan Desa bisa mengembangkan alternatif layanannya secara lebih proaktif dan kreatif. Apalagi di era online seperti sekarang, ketika sektor lain sudah mengembangkan jenis kegiatannya dengan basis digital dan online, maka perpustakaan pun sudah seharusnya menjadi fasilitator pengembangan dimaksud. Salah satu caranya adalah mengembangkan model layanan implementasi hasil membaca. Jadi bukan sekadar memfasilitasi orang membaca, namun lebih kepada membantu orang lain mengimplementasikan isi bacaannya. Perpustakaan Desa tidak hanya menyediakan buku Teknik Memelihara Ayam Kampung, Teknik Budidaya Jamur Merang, Teknik 
Membuat Telor Asin, dan jenis buku TTG lainnya, namun yang lebih penting adalah memfasilitasi pembacanya, terutama dari kelompok miskin di pedesaan, untuk mencoba mengimplementasikan isi dari buku dimaksud. Perpustakaan Desa bisa memfasilitasi kegiatan pelatihan usaha berbasis membaca buku TTG.

\section{A. KESIMPULAN}

Rintisan pembangunan sistem usaha bersama kelompok tani berupa lumbung padi (lumbung paceklik) di desa, bisa dilakukan dengan memperhatikan unsur-sunsur yang terkait. Salah satunya adalah perlu memperhatikan sistem pengetahuan lokal yang berkarakter kebersamaan, kesetiakawanan, gotong royong, dan terbukti tangguh dalam menghadapi perubahan global. Untuk memulainya diperlukan langkah-langkah teknis-strategis dan terpadu, yang melibatkan berbagai unsur terkait, seperti perguruan tinggi, badan usaha yang ada di desa, pemuka masyarakat, kelompok usaha masyarakat, perpustakaan desa, dan unsur lainnya. Adapun langkah teknis yang dilakukan untuk memulainya adalah: (1) Menggali informasi awal melalui diskusi dengan masyarakat mengenai peta permasalahan kemiskinan pedesaan dilihat dari aspek penyediaan sarana pelatihan usaha berbasis membaca sumbersumber informasi kewirausahaan. (2) Melakukan proses pembelajaran bersama masyarakat miskin pedesaan mengenai potensi usaha di desa atas dasar pandangan dan pengalaman mereka. (3) Menyusun model usaha berbasis pemanfaatan sumber bacaan yang cocok dengan jenis usaha di desa. (4) Melakukan diskusi mengenai rintisan penyelenggaraan kelompok usaha berbasis Lumbung Padi di desa, yang terbukti tahan terhadap perubahan global. (5) Mensinergikan semua kegiatan yang dilakukan oleh masingmasing unsur di atas, dalam bentuk model harmoni desa tani, penduduk miskin, lumbung padi, dan perpustakaan desa.

Ada beberapa hal yang perlu diperhatikan sebelum memulai menyelenggarakan sistem usaha lumbung padi. Para inisiator perlu memperhatikan unsur-unsur dominan yang ada di lingkungan pedesaan. Beberapa di antaranya adalah kondisi desa tani, kondisi penduduk berkategori miskin setempat, sarana dan prasarana sistem usaha lumbung padi, termasuk sistem pemodalannya. Selain itu, upaya optimalisasi kinerja layanan perpustakaan desa dan perpustakaan masyarakat yang ada di desa dalam melakukan fungs-fungsi layanan implementatifnya, sangat diperlukan untuk membantu mempercepat proses pembangunan di wilayah pedesaan.

\section{DAFTAR PUSTAKA}

Adimihardja, Kusnaka \& Harry Hikmat (2003). Participatory Research Appraisal: Pengabdian dan Pemberdayaan Masyarakat. Humaniora, Bandung.

Badruddin, Syamsiah, (2009). Miskin dan Kesenjangan Sosial di Indonesia Pra dan Pasca Runtuhnya Orde Baru. Available at: http://profsyamsiah. wordpress.com/ 2009/04/23/49/

Bank Dunia (2016). Situs resmi bank dunia pada: http://go.worldbank.org, diakses tanggal 2 Pebruari 2016.

Gerbang Pertanian (2010). Lumbung Desa Sebagai Penopang Petani Di Saat Paceklik. Gerbang Pertanian@2010-2015. May 19, 2010. Purwokerto, Jawa Tengah.

Handayani, Sri (2009). Penerapan Metode Penelitian Participatory Research Apraisal Dalam Penelitian Permukiman Vernakular (Permukiman Kampung Kota). Dimuat dalam prosiding Seminar Nasional Penelitian Arsitektur - Metoda dan Penerapannya Seri 2 UNDIP Semarang, 2009.

Hermawan, Iwan (2012). Analisis Eksistensi Sektor Pertanian terhadap Pengurangan Kemiskinan di Pedesaan dan Perkotaan. $M I M B A R$, Vol. 28, No. 2 (Desember, 2012): 135-144.

Infoniaga (2003). Lumbung Desa: Kearifan Pengelolaan Pangan yang Habis Dikerat Zaman. Infoniaga, April 2003). 
Lestari, Syahnaz Yuliana; Komariah, Neneng; dan Rizal, Edwin (2016). Pengelolaan Informasi sebagai Upaya Memenuhi Kebutuhan Informasi Masyarakat: Studi Kualitatif Pengelolaan Informasi Dinas Komunikasi dan Informatika Kabupaten Garut. Jurnal Kajian Informasi dan Perpustakaan. Vol 4, No 1, Juni 2016, halaman 59-68. ISSN: 2303-2677

Nashihuddin, Wahid dan Tupan (2016). Manajemen Layanan Kemas Ulang Informasi Digital Di PDII LIPI. Lentera Pustaka 2 (2): 95-106, 2016. Available Online at: http://ejournal.undip.ac.id /index.php/lpustaka.

Orang Pinggiran (2012-2015). Program Siaran Televisi Trans7 (2012-2017). Seri Orangorang Pinggiran.

Rosfiantika, Evi dan Yusup, Pawit M. (2015). Belajar Bersama Para Jamaah di Perpustakaan Masjid. Jurnal Kajian Informasi dan Perpustakaan. Volume 3. Nomor 2. Desember 2015. ISSN: 23032677.

Yusup, Pawit M. (2013). Makna Diri Penduduk Miskin Pedesaan. Indonesian Journal of DIALECTICS-IJAD. Vol 3, No. 2, 2013: 86.

Yusup, Pawit M. (2013). Memetakan jenis kebutuhan utama orang miskin pedesaan dan informasi penghidupan yang dicarinya. Jurnal Kajian Informasi dan Perpustakaan, volume 1 Nomor 1, Juni 2013.
Yusup, Pawit M. and Komariah, Neneng. (2014). Health Information Seeking and Use Among Rural Poor Families in West Java, Indonesia. Brazilian Journal of Information Science (BRAJIS). 2014: Vol 8, No. 1-2.

Yusup, Pawit M.; Rahmawati, Tine Silvana; Subekti, Priyo (2014). Memaknai Kemiskinan Berdasarkan Pandangan Orang Miskin Pedesaan. Edulib. Journal of Library and Information Science. Tahun 3. Volume 1. Nomor 1. ISSN. 2089-6549.

Yusup, Pawit M.; Rohanda, dan Subekti, Priyo (2015). Makna Miskin Menurut Pandangan Keluarga Miskin Pedesaan. Prosiding Kepustakawanan Indonesia 2015. Library Move On. 19-21 Agustus 2015. Universitas Pendidikan Indonesia. ISBN: 978-60295858-2-7 (halaman 297).

Yusup, Pawit M.; Subekti, Priyo; dan Anwar, Rully Khairul (2014). Uji Coba Praktik Layanan Perpustakaan dan Taman Bacaan Masyarakat (TBM) Berorientasi Wirausaha bagi Penduduk Miskin Pedesaan. Shaut alMaktabah: Jurnal Ilmu Perpustakaan, vol 6, nomor 2, November 2014. Hal 20-35. ISSN: 2339-1456. 